\title{
Evaluasi Terapi Adjuvant Hormonal dan Hubungannya Terhadap Outcome Klinis Pasien Kanker Payudara Stadium Dini di Kota Padang
}

(Hormonal Adjuvant Therapy Evaluation and Correlation With Clinical Outcome on Breast Cancer Patients in Padang)

\author{
Fatma Sri Wahyuni ${ }^{1 *}$, Wessi Windrasari ${ }^{1}$, dan Daan Khambri ${ }^{2}$ \\ ${ }^{1}$ Fakultas Farmasi, Universitas Andalas, \\ ${ }^{2}$ Bagian Bedah Divisi Bedah Onkologi RSUP Dr. M. Djamil Padang
}

\begin{abstract}
Hormonal adjuvant therapy is an effective therapeutic option for early stage breast cancer patients with hormonal responsive and Her-2 negative. The clinical outcomes of breast cancer are Disease Free Survival (DFS) and Overall Survival (OS). This study aimed to evaluate and correlate hormonal adjuvant therapy on clinical outcomes (DFS and OS). This study was a descriptive of cross-sectional design that retrospective collecting the data from breast cancer registration of Indonesian Society of Surgical Oncology (ISSO) Padang during the period 2008-2017. The data was analysis statistically by using Kaplan Meier analyzed with Log-rank. The result was found 58 patients in inclusion criteria, with an average age of $49.41 \pm 8.69$ years, the incidence of relapse was $22.4 \%$ and $6,9 \%$ was died. The most hormonal adjuvant therapy in premenopausal patients was tamoxifen (58.3\%), in postmenopausal patients were Aromatase Inhibitors (54.5\%). Statistically, in premenopausal patients there was no different between hormonal adjuvant therapy on DFS (P log-rank test 0.243 and HR $=0.513$ ) and OS ( $\mathrm{P}$ log-rank test 0.545 and $H R=0.314$ ). Similar in postmenopausal patients, there was no different between hormonal adjuvant therapy on DFS ( $P$ log rank test 0.586 and $H R=0.10)$ and $O S(P$ log-rank test 0.594 and $H R=0.12)$.
\end{abstract}

Keywords: Disease Free Survival (DFS); hormonal adjuvant therapy; Overall Survival (OS), premenopausal; postmenopausal.

ABSTRAK: Terapi adjuvant hormonal merupakan pilihan terapi yang efektif bagi pasien kanker payudara stadium dini dengan hormonal responsif dan Her-2 negatif. Outcome klinis dari terapi kanker payudara adalah Disease Free Survival (DFS), Overall Survival (OS). Penelitian ini bertujuan mengevaluasi terapi adjuvant hormonal dan pengaruhnya terhadap outcome klinis pasien. Penelitian ini merupakan penelitian deskriptif dengan desain cross sectional study menggunakan data retrospektif registrasi kanker payudara Persatuan Ahli Bedah Onkologi Indonesia (PERABOI) Kota Padang selama periode 2008-2017. Analisis data menggunakan Kaplan Meier Analysis dengan Log rank. Diperoleh sebanyak 58 orang pasien yang memenuhi kriteri inklusi, dengan rerata umur yaitu 49,41 \pm 8,69 tahun, kejadian relaps 22,4\% dan sebanyak 6,9\% pasien mengalami kematian. Terapi terbanyak pada pasien premenopause adalah tamoxifen (58,3\%), pada pasien pascamenopause adalah Aromatase Inhibitor (54,5\%). Secara statistik pada pasien premenopause tidak ada pengaruh terapi adjuvant hormonal yang berbeda terhadap DFS (P log rank test 0,243 dan HR $=0.513$ ) dan OS ( $P$ log rank test 0,545 dan HR = 0.314). Pada pasien pascamenopause tidak ada pengaruh terapi yang berbeda terhadap DFS ( $P$ log rank test 0,586 dan HR = 0,10) dan OS (P log rank test 0,594 dan HR=0,12).

Kata kunci: Disease Free Survival (DFS); Overall Survival (OS); terapi adjuvant hormonal; premenopause, pascamenopause.

\section{Pendahuluan}

Kanker payudara adalah salah satu keganasan terbanyak pada wanita dan sejauh ini sebanyak 1,7 juta kasus baru kanker payudara pada wanita di diagnosis pada tahun 2012 (25\% dari semua jenis kanker). Berdasarkan data WHO kanker payudara menempati urutan pertama dari seluruh kanker pada perempuan (tingkat kejadian 38 per 100.000 perempuan) [1].

Kanker payudara merupakan salah satu jenis kanker yang sering terjadi pada perempuan di Indonesia dengan kontribusi sebesar 30\% mengalahkan kanker serviks yang berkontribusi sebesar 24\% [2]. Angka kejadian kanker payudara di Indonesia adalah 0,5 per 1000. Berdasarkan data Kemenkes tahun 2013 tentang Prevalensi dan Estimasi jumlah penderita kanker payudara pada penduduk perempuan Propinsi sumatera Barat angka kejadian kanker payudara lebih tinggi dari rata-rata yaitu 0,8 per 1000 sehingga Sumatera Barat menduduki urutan ketiga setelah Provinsi Yogyakarta dan Kalimantan Timur [2]. Registrasi kanker payudara PERABOI (Persatuan Ahli Bedah Onkologi) Kota Padang sampai tahun 2016 mencatat sebanyak 604 orang
Access this article

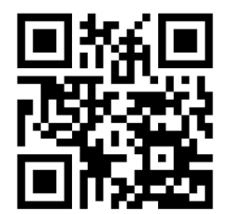


penderita kanker payudara di Kota Padang.

Kanker payudara stadium dini merupakan kanker payudara yang masih dapat dilakukan pembedahan (operable) karena sel kanker belum mengalami metastasis, meliputi stadium 0, I, IIa, IIb dan terjadi pada pasien premenopause dan pascamenopause [3,4]. Tata laksana terapi kanker payudara stadium dini dengan hormon responsif dan Her-2 negatif dengan pembedahan dan terapi adjuvant hormonal. Hormon responsif ditandai dengan keterlibatan Estrogen Receptor (ER) dan Progesteron Receptor (PR) yang diperoleh dengan pemeriksaan imunohistokimia (IHK) [5-9].

Outcome klinis dari terapi kanker payudara adalah Disease Free Survival (DFS), Overall Survival (OS) dan angka kejadian relaps pada pasien. Tingkat keberhasilan terapi adjuvant hormonal pada pasien kanker payudara stadium dini diukur dengan meningkatnya kelangsungan hidup bebas penyakit (DFS), menurunnya risiko relaps dan kematian (OS) [3,12-14].

Secara umum kerja terapi adjuvant hormonal adalah mencegah pertumbuhan dan perkembangan kanker yang diduga berkaitan dengan peran hormon estrogen yang menyebabkan proliferasi dan pertumbuhan sel kanker payudara. Terapi adjuvant hormonal meliputi obatobat golongan Selective Estrogen Modulator (SERM) dan Aromatase Inbibitor (AI) dan Luteinizing Hormone Releasing Hormon (LHRH) [5,6]. Pada konsensus St. Gallen 2015, pasien premenopause dengan hormon responsif sebagai terapi utama diberikan OFS (Ovarian Function Suppresion)/ agonis LHRH yang diikuti dengan pemberian Tamoxifen (SERM) atau dengan terapi Tamoxifen saja, sedangkan untuk pasien pascamenopause diberikan Tamoxifen saja atau switch AI [12-14].

Penelitian ini bertujuan untuk mengetahui hubungan terapi adjuvant hormonal yang diberikan dengan outcome klinis pasien kanker payudara stadium dini di Kota Padang Tahun 2008-2017. Melalui penelitian ini diharapkan dapat menjadi masukan dalam upaya meningkatkan outcome klinis pasien khususnya pada pasien kanker payudara stadium dini melalui pemberian terapi adjuvant hormonal yang efektif.

\section{Metode Penelitian}

\section{Rancangan Penelitian}

Penelitian ini adalah penelitian deskriptif dengan desain cross sectional study menggunakan data retrospektif yang diperoleh dari registrasi kanker payudara Persatuan Ahli Bedah Onkologi Indonesia (PERABOI) selama periode 2008-2017.
Penetapan Sampel

Kriteria inklusi meliputi seluruh pasien kanker payudara stadium dini yang menjalani mastektomi dan mendapatkan terapi adjuvant hormonal periode 20082017 dengan status hormonal responsif, Her-2 negatif dan mendapatkan terapi adjuvant hormonal. Kriteria eksklusi meliputi kanker payudara dengan penyakit penyerta, pasien ablasi ovarium, data pasien tidak lengkap.

\section{Pengumpulan Data}

Dilakukan secara retrospektif dari data registrasi kanker payudara Persatuan Ahli Bedah Onkologi Indonesia (PERABOI) Kota Padang selama periode 2008-2017. Data berupa karakteristik pasien yaitu usia, alamat, pendidikan, pekerjaan, status pernikahan, status menopause, histopatologi,status PR, tanggal kasus, terapi hormonal yang digunakan, waktu mulai pemberian terapi, relaps dan kematian pasien.

\section{Analisa Data}

Data yang dikumpulkan dianalisa secara statistik untuk menggambarkan distribusi frekuensi kejadian kanker payudara berdasarkan karakteristik pasien serta gambaran terapi adjuvant hormonal yang digunakan, setiap variabel disajikan dalam bentuk tabel persentase dan mengggunakan Kaplan Meier Analyzed dengan Log rank untuk menggambarkan hubungan terapi adjuvant hormonal yang diberikan terhadap outcome klinis (DFS dan OS).

\section{Hasil dan Diskusi}

Berdasarkan data dari registrasi kanker payudara PERABOI Kota Padang diperoleh subjek penelitian yang memenuhi kriteria inklusi sebanyak 58 sampel. Karakteristik pasien kanker payudara stadium dini di kota Padang tahun 2008-2017 dapat dilihat pada tabel 1.

Distribusi usia penderita kanker payudara yang ditemukan pada penelitian ini berada pada usia 49,41 \pm 8,69 . Hal ini sesuai dengan teori bahwa kejadian puncak kanker payudara terjadi pada umur 40-50 tahun [15]. Penelitian terhadap pasien kanker payudara stadium dini di RSUP Dr. Sardjito Yogyakarta juga menunjukkan usia 40-50 tahun[16]. Usia merupakan faktor risiko yang paling penting. Namun meningkatnya risiko kanker payudara oleh bertambahnya usia juga ditentukan oleh faktor risiko lainnya yang dimiliki oleh tiap individu [17].

Riwayat pendidikan yang ditemukan pada penelitian ini menunjukkan bahwa paling banyak penderita kanker 
Tabel 1. Karakteristik pasien kanker payudara stadium dini di Kota Padang pada tahun 2008-2017

\begin{tabular}{|c|c|c|c|}
\hline \multicolumn{2}{|c|}{ Karakteristik } & \multirow{2}{*}{$\begin{array}{c}\text { Frekuensi } \\
\text { (f) }\end{array}$} & \multirow{2}{*}{$\begin{array}{c}\text { Persentase } \\
\text { (\%) }\end{array}$} \\
\hline Umur (tahun) & $49,41 \pm 8,69$ & & \\
\hline \multirow{5}{*}{ Pendidikan } & Tamat SD & 5 & 8,6 \\
\hline & Tamat SMP & 10 & 17,2 \\
\hline & Tamat SMA & 21 & 36,2 \\
\hline & Tamat Diploma & 4 & 6,9 \\
\hline & Tamat S1 & 18 & 31 \\
\hline \multirow{4}{*}{ Pekerjaan } & PNS & 17 & 29,3 \\
\hline & Pegawai Swasta & 3 & 5,2 \\
\hline & Ibu Rumah Tangga & 37 & 63,8 \\
\hline & Lainnya & 1 & 1,7 \\
\hline \multirow{2}{*}{ Status Pernikahan } & Menikah & 52 & 89,7 \\
\hline & Janda & 6 & 10,3 \\
\hline \multirow{2}{*}{ Status Menopause } & Premenopause & 36 & 62,1 \\
\hline & Pascamenopause & 22 & 37,9 \\
\hline \multirow{4}{*}{ Histopatologi } & IDC & 45 & 77,6 \\
\hline & Atypical Ductal & 1 & 1,7 \\
\hline & Ductal Carcinoma in Situ & 4 & 6,9 \\
\hline & ILC & 8 & 13,8 \\
\hline \multirow{2}{*}{ Progesteron Reseptor } & Negatif & 13 & 22,4 \\
\hline & Positif & 45 & 77,6 \\
\hline \multirow{4}{*}{ Terapi Adjuvan Hormonal } & Al & 13 & 22,4 \\
\hline & Tamoxifen & 31 & 53,4 \\
\hline & Goserelin inj + Tamoxifen & 12 & 20,7 \\
\hline & Goserelin inj & 2 & 3,4 \\
\hline \multirow{4}{*}{ Outcome } & Relaps & 13 & 22,4 \\
\hline & Tidak Relaps & 45 & 77,6 \\
\hline & Hidup & 54 & 93,1 \\
\hline & Mati & 4 & 6,9 \\
\hline
\end{tabular}

payudara stadium dini adalah SMA (36,2\%) dan S1 (31\%). Hal ini sejalan dengan penelitian oleh Dananjaya (2017) yang menunjukkan sekitar $71,3 \%$ penderita merupakan pasien dengan riwayat pendidikan SMA ke atas. Hal ini mungkin menunjukkan keinginan berobat ke rumah sakit lebih tinggi pada wanita dengan pendidikan tinggi [18].

Karakteristik pekerjaan pada penelitian ini ditemukan bahwa 63,8\% pasien merupakan ibu rumah tangga. Hal ini sedikit lebih banyak jika dibandingkan dengan penelitian oleh Megawati (2012), yang menunjukkan 55,8\% dari 138 orang yang diteliti merupakan golongan ibu rumah tangga atau tidak bekerja serta penelitian Dananjaya (2017) sebanyak 60\% merupakan golongan ibu rumah tangga.

Pada penelitian ini diperoleh pasien terbanyak dengan status menikah yaitu $89,7 \%$ sementara pasien dengan status janda sebanyak 10,3\%. Dalam penelitian ini tidak ditemukan pasien dengan status tidak menikah. Faktor hormon endogen (estrogen dan progesteron) dan eksogen (kontrasepsi oral dan terapi sulih hormon) menyebabkan proliferasi sel epitel payudara dan merupakan ransangan karsinogenik sehingga merupakan resiko yang lebih tinggi untuk terjadinya kanker payudara [17].

Diketahui pasien premenopause sebanyak $62,1 \%$ dan pascamenopause sebanyak 37,9\%. Hal ini berbeda dengan penelitian Dananjaya (2017) terhadap 100 orang pasien kanker payudara stadium dini di RSUP M.Djamil Padang ditemukan pasien premenopause sebanyak $46 \%$ dan pasien pascamenopause sebanyak 54\%. Faktor risiko untuk 
kanker payudara premenopause dan pascamenopause ditemukan serupa, tetapi risiko terkena kanker meningkat seiring bertambahnya usia seorang wanita. Seorang wanita yang mengalami menopause setelah usia 55 tahun memiliki peningkatan risiko kanker payudara. Risikonya lebih besar jika seorang wanita juga mulai menstruasi sebelum usia 12 tahun. Paparan yang lebih lama terhadap estrogen meningkatkan risiko seorang wanita terkena kanker payudara. Oleh karena itu, wanita yang telah mengalami menopause alami lebih mungkin beresiko kanker sekitar dua kali lebih tinggi karena faktor hormonal. Lebih banyaknya pasien premenopause $(62,1 \%)$ pada penelitian ini lebih dapat dijelaskan salah satunya dikarenakan risiko yang lebih besar jika seorang wanita mulai menstruasi sebelum usia 12 tahun dan dengan heterogenitas pada kanker payudara yang diketahui sebagai salah satu penentu outcome klinis [20,21].

Pada pemeriksaan histopatologi didapatkan terbanyak pada jenis Invasif Ductal Carsinoma (IDC) sebanyak 77,58\% dan Invasif Lobular Carsinoma (ILC) sebanyak 13,79\%. Penelitian di Indonesia maupun di negara negara benua Asia, Afrika, dan Eropa dan Amerika menunjukkan bahwa IDC merupakan tipe histopatologis yang paling banyak ditemukan dan merupakan prognosis yang buruk dibandingkan tipe ILC [3,22]. Sementara itu laporan kejadian tipe kanker payudara di Yogyakarta pada tahun 2006 didapatkan jenis histologis terbanyak adalah IDC (78\%), diikuti ILC (9\%) dan tipe-tipe lain (13\%) (Aryandono et al., 2006). Penelitian Rukminingsih terhadap pasien kanker payudara stadium dini menunjukkan tipe IDC sebanyak 93,34\% [16]. Penelitian Irwan di RSUP dr M.Djamil Padang juga menunjukkan tipe IDC sebanyak 72,9\% [23].

Pada pasien premenopause (gambar 1)terapi adjuvant hormonal yang diberikan adalah tamoxifen (58,3\%), goserelin inj + tamoxifen $(33,3 \%)$ dan goserelin inj (5,6\%). Penggunaan tamoxifen direkomendasikan sebagai terapi lini pertama pada pasien kanker payudara dengan $\operatorname{ER}(+)$ [6,8]. Sementara itu pasien pascamenopause (gambar 2) lebih banyak diberikan AI (54,5\%), sedangkan pemberian tamoxifen $45,5 \%$ (Tabel 2). Menurut The National Comprehensive Cancer Network Guideline 2016 pada pasien pascamenopause dapat diberikan AI / tamoxifen secara tunggal secara bersamaan (concurrent) atau berurutan (sequential) [24]). Pada penelitian ini diperoleh sebanyak 93,1\% pasien hidup hingga akhir follow up. Pada penelitian lain Gu Ran, 2012 di China terhadap 240 orang pasien kanker payudara stadium dini dan reseptor hormon positif yang menggunakan Tamoxifen selama 5 tahun diperoleh sebanyak 77,7\% yang hidup [25].
Menggunakan Kaplan Meier Analysis dengan Log rank (gambar 3) diperoleh bahwa tidak terdapat pengaruh pemberian terapi adjuvant hormonal yang berbeda pada pasien premenopause terhadap disease free survival ( $\mathrm{P}$ log rank. test 0,243 dan $\mathrm{HR}=0.513$ ) dan terhadap overall survival (P log rank test 0,545 dan $\mathrm{HR}=0.314)$. Meskipun secara statistik tidak terdapat pengaruh terhadap DFS namun dari Tabel $\underline{3}$ diketahui DFS pada pasien premenopause dengan terapi goserelin inj yaitu 48 bulan, lebih tinggi jika dibandingkan goserelin inj + tamoxifen 30,8 bulan, tamoxifen 19,7 bulan dan AI 7 bulan. Pemberian goserelin inj memberikan DFS yang lebih tinggi (48 bulan) dibandingkan dengan pemberian goserelin inj + tamoxifen (30,8 bulan). Penelitian lain terhadap 171 orang pasien kanker payudara stadium dini premenopause dengan terapi kombinasi goserelin plus tamoxifen dan dengan terapi tamoxifen saja menunjukkan tidak terdapat perbedaan yang signifikan terhadap DFS kedua terapi tersebut, dengan $\mathrm{P}$ value $=$ 0,62 [26].

Diperoleh OS pada pasien premenopause berdasarkan terapi adjuvan hormonal goserelin inj yaitu 48 bulan, lebih tinggi jika dibandingkan goserelin inj + tamoxifen 42,25 bulan, tamoxifen 19,7 bulan dan AI 14 bulan. Pemberian tamoxifen sebagai terapi adjuvant setelah operasi pada pasien kanker payudara tidak memberikan perbedaan OS yang signifikan (P log rank $=0,517$ ) [10]. Manfaat tamoxifen sebagai terapi adjuvant adalah signifikan secara statistik pada tahun 7 sampai 9 tahun hingga tahun 10 sampai 14, sedangkan untuk periode waktu yang lebih pendek atau lebih, perbedaan tersebut tidak signifikan [27,28].

Menggunakan Kaplan Meier Analysis dengan Log rank (gambar 4) tidak terdapat pengaruh pemberian terapi adjuvan hormonal yang berbeda pada pasien pascamenopause terhadap DFS (P log rank test 0,586 dan $H R=0,10)$ dan OS (P log rank test 0,594 dan HR $=0,12$ ). Meskipun secara statistik tidak terdapat pengaruh terhadap DFS namun dari Tabel 4 terlihat DFS pada pasien pascamenopause berdasarkan terapi adjuvan hormonal AI yaitu 21,2 bulan sedikit lebih tinggi jika dibandingkan tamoxifen 18,7 bulan. Pada suatu penelitian dari Early Breast Cancer Trialists Collaborative Group (EBCTCG) terhadap 9885 orang pasien pascamenopause stadium dini yang diberikan AI yang di follow up selama 10 tahun memberikan DFS yang lebih tinggi dibandingkan dengan pemberian tamoxifen. Hal ini menunjukkan bahwa pada pasien kanker payudara stadium dini pascamenopause, terapi adjuvant hormonal dengan AI mengurangi risiko relaps dan meningkatkan kelangsungan hidup secara keseluruhan, dibandingkan dengan pemberian tamoxifen saja sebagai terapi adjuvant hormonal [13]. 


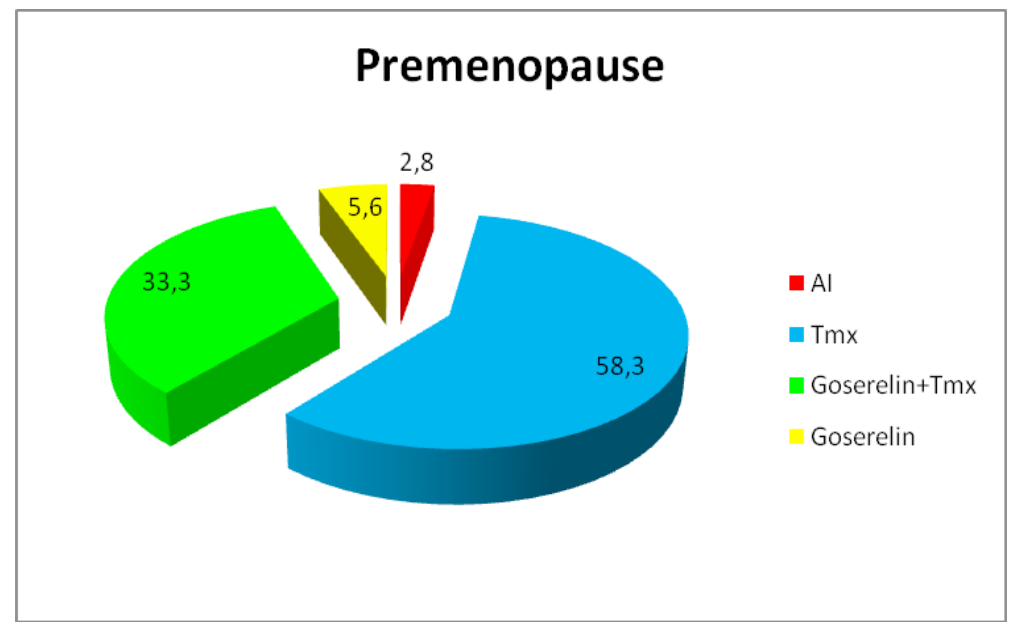

Gambar 1. Terapi adjuvant hormonal pada pasien Premenopause

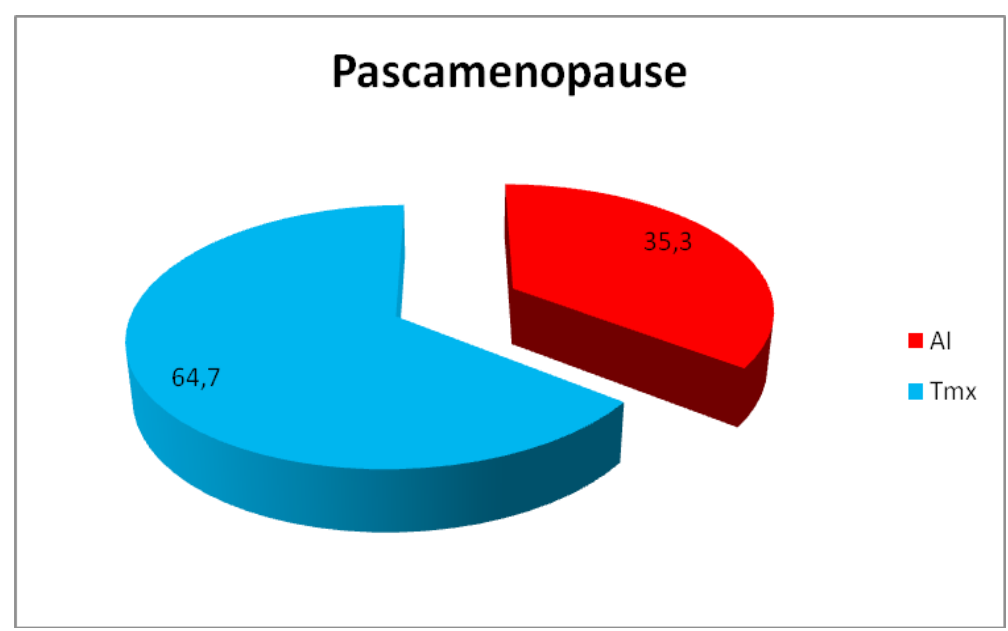

Gambar 2. Terapi adjuvant hormonal pada pasien Pascamenopause

Tabel 2. Terapi adjuvant hormonal yang diberikan pada pasienpremenopause dan pascamenopause kanker payudara stadium dini di Kota Padang pada tahun 2008-2017

\begin{tabular}{|c|c|c|c|c|c|c|}
\hline \multirow{3}{*}{ Terapi Adjuvant Hormonal } & \multicolumn{4}{|c|}{ Status Menopause } & \multirow{2}{*}{\multicolumn{2}{|c|}{ Jumlah }} \\
\hline & \multicolumn{2}{|c|}{ Premenopause } & \multicolumn{2}{|c|}{ Pascamenopause } & & \\
\hline & f & $\%$ & f & $\%$ & f & $\%$ \\
\hline Aromatase Inhibitor & 1 & 2,8 & 12 & 54,5 & 13 & 22,4 \\
\hline Tamoxifen & 21 & 58,3 & 10 & 45,5 & 31 & 53,4 \\
\hline Goserelin inj + tamoxifen & 12 & 33,3 & 0 & 0 & 12 & 20,7 \\
\hline Goserelin inj & 2 & 5,6 & 0 & 0 & 2 & 3,4 \\
\hline Jumlah & 36 & 100 & 22 & 100 & 58 & 100 \\
\hline
\end{tabular}




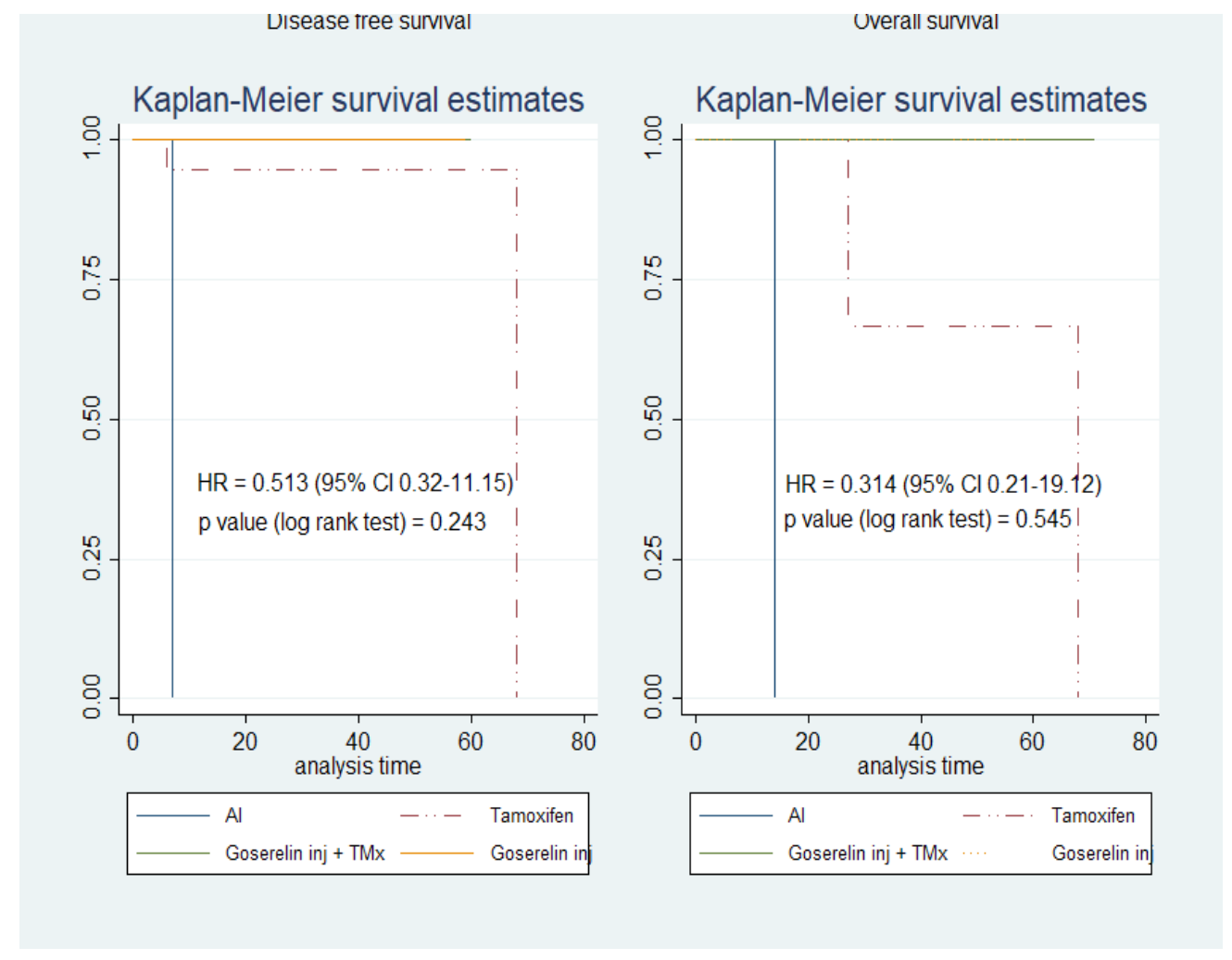

Gambar 3. Grafik Kaplan Meier Pengaruh Terapi Adjuvant Hormonal pada Pasien Premenopause terhadap Disease Free Survival (DFS) dan Overall Survival (OS)

Tabel 3. Pengaruh Terapi adjuvant Hormonal pada Pasien Premenopause terhadap Disease Free Survival dan Overall Survival

\begin{tabular}{|c|c|c|c|c|c|c|c|}
\hline & $\begin{array}{c}\text { Terapi Adjuvant } \\
\text { Hormonal }\end{array}$ & Event & Censoring & Mean & Hazard Rasio & $95 \% \mathrm{Cl}$ & $\begin{array}{c}\text { P value } \\
\text { (Log-rank test) }\end{array}$ \\
\hline \multirow{4}{*}{ DFS } & Aromatase Inhibitor & 1 & 0 & 7 & \multirow{4}{*}{0,513} & \multirow{4}{*}{$0,32-11,15$} & \multirow{4}{*}{0.243} \\
\hline & Tamoxifen & 2 & 19 & 19,7 & & & \\
\hline & Goserelin inj + tamoxifen & 0 & 12 & 30,8 & & & \\
\hline & Goserelin inj & 0 & 2 & 48 & & & \\
\hline \multirow{4}{*}{ OS } & Aromatase Inhibitor & 1 & 0 & 14 & \multirow{4}{*}{0.314} & \multirow{4}{*}{$0,21-19,12$} & \multirow{4}{*}{0.545} \\
\hline & Tamoxifen & 2 & 19 & 19,7 & & & \\
\hline & Goserelin inj + tamoxifen & 0 & 12 & 42,25 & & & \\
\hline & Goserelin inj & 0 & 2 & 48 & & & \\
\hline
\end{tabular}




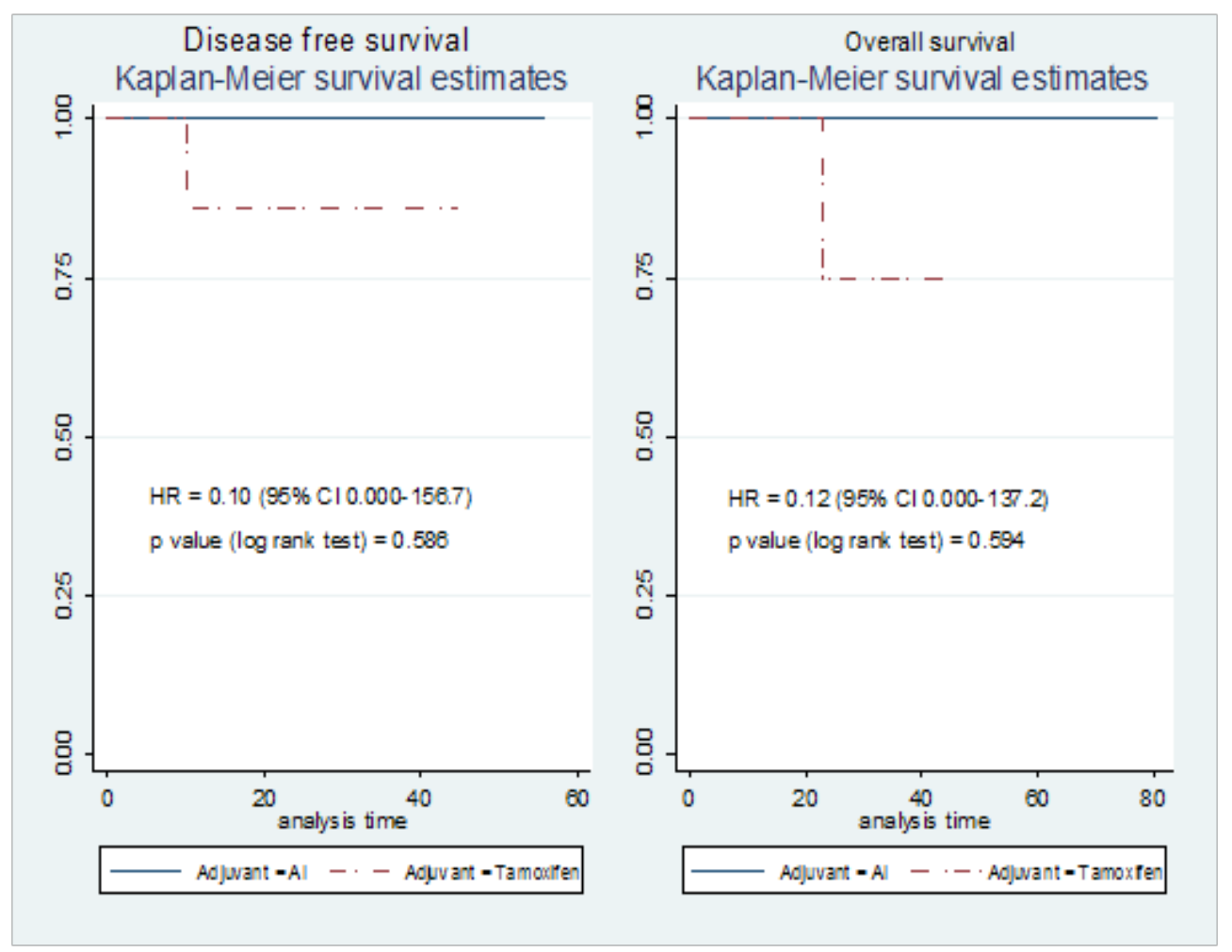

Gambar 4. Grafik Kaplan Meier Pengaruh Terapi Adjuvant Hormonal pada Pasien Pascamenopause terhadap Disease Free Survival (DFS) dan Overall Survival (OS)

Tabel 4. Pengaruh terapi adjuvant hormonal pada Pasien Pascamenopause berdasarkan terhadap Disease Free Survival dan Overall Survival

\begin{tabular}{|clcccccc|}
\hline & \multicolumn{1}{c}{$\begin{array}{c}\text { Terapi Adjuvant } \\
\text { Hormonal }\end{array}$} & Event & Censoring & Mean & Hazard Rasio & $\mathbf{9 5 \%} \mathbf{C l}$ & $\begin{array}{c}\text { P value } \\
\text { (Log-rank test) }\end{array}$ \\
\hline \multirow{2}{*}{ DFS } & Aromatase Inhibitor & 0 & 12 & 21,2 & 0,10 & $0,000-156,7$ & 0,586 \\
& Tamoxifen & 1 & 9 & 18,7 & & & 0,594 \\
\hline \multirow{2}{*}{ OS } & Aromatase Inhibitor & 0 & 12 & 25,8 & 0,12 & $0,000-137,2$ & \\
\hline
\end{tabular}




\section{RELAPS/TIDAK RELAPS}

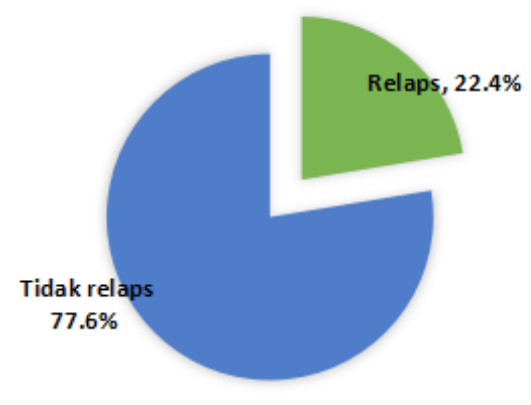

Gambar 5. Outcome klinis Relaps/ Tidak Relaps

OS pada pasien pascamenopause (Tabel 4) dengan terapi adjuvant hormonal AI yaitu 25,8 bulan lebih tinggi jika dibandingkan tamoxifen 19,7 bulan. Tidak terdapat pengaruh pemberian terapi adjuvant hormonal yang berbeda pada pasien pascamenopause terhadap OS (P $\log$ rank test 0,594 dan $\mathrm{HR}=0,12)$. Pemberian tamoxifen sebagai terapi adjuvan setelah operasi pada pasien kanker payudara tidak memberikan perbedaan overall survival yang signifikan $(\mathrm{P} \log$ rank $=0,517$ ). Suatu studi yang menilai efektivitas terapi adjuvan hormonal pada pasien pascamenopause dengan median follow up 1,2,3 tahun menyebutkan tidak ada perbedaan bermakna dalam OS dan DFS pada pemberian secara bersamaan (concurrent) atau berurutan (sequential) dan pada pasien pascamenopause pemberian AI atau pemberian tamoxifen mempunyai angka ketahanan hidup yang sama [30].

Dari penelitian ini diketahui sebanyak 22,4\% pasien kanker payudara stadium dini mengalami relaps (gambar 5). Angka ini lebih kecil dibandingkan dengan hasil penelitian Rukminingsih tentang terapi adjuvant dan kejadian relaps pada pasien kanker payudara stadium dini premenopause di RS Sardjito, Yogyakarta dimana didapat kekambuhan sebesar 36,67\% [16].

\section{Kesimpulan}

Dari penelitian ini tidak terdapat pengaruh yang signifikan secara statistik antara terapi adjuvant hormonal yang berbeda terhadap Outcome klinis pasien kanker payudara stadium dini di kota Padang.

\section{Referensi}

[1] International Agency for Research on Cancer, WHO. 2013. Latest world cancer statistic Global Cancer burden rises to 14,1 million new cases in 2012.

[2] Pusat Data dan Informasi Kementrian Kesehatan RI. 2015. Situasi Penyakit kanker. Buletin Jendela Data dan Informasi Kesehatan.

[3] Burstein HJ,Prestrud AA. and Seidenfeld J. American Society of Clinical Oncology clinical practice guideline: update on adjuvant endocrine therapy for women with hormone receptor-positive breast cancer. J Clin Oncol. 2014.28(23):84-3796.

[4] Edge, SB, Byrd DR, Compton CC. AJCC Cancer Staging Manual 7th ed. Annals of Surgical Oncology. 2010:17 (6): 71--1474.

[5] Freedman, O.C., G.G. Fletcher., S.Gandhi, M.Mates., S.F. Dent., M.E. Trudeau. Adjuvant endocrine therapy for early breast cancer : a systematic review of the evidence for 2014 Cancer Care Ontario systemic therapy guideline. Current Oncology. 2015; 22 (1): 95-113.

[6] Brunton, LL, Bruce C. and Bjorn K. Goodman and Gilman's The Pharmacological Basis of Therapeutics. Twelfth edition. New York : The McGraw- Hill Companies Inc ; 2011.

[7] Senkus E, Kyriakides S, Ohno S, Liorca P, Portmans P, Rutgers E, Zackrisson S,Cordoso F. Clinical Practice Guidelines for diagnosis, treatment and Follow up. Ann of Oncology. 2015 ;26(5):8-30.

[8] Kementerian Kesehatan. Panduan Nasional Penanganan Kanker Payudara. 2015

[9] Gnant M. Zolendronic acid in breast cancer : Latest findings and Interpretation. Med.Oncol. 2011; 3(6) : 293-301.

[10] Aryandono T, Harijadi S, Soeripto. Hormone Receptor status operable Breast Cancer in Indonesia : Correlation with other prognostic factors and survival. Asian Pacific J Cancer Prev. 2006; 7: 21-324.

[11] Shrigondekar P, Desail S, Bhosale S, Mankar D, Badwe A. Study of Hormone Receptor Status of Breast Carcinoma and Its Correlation with the Established Prognostic Markers. International Journal of Health Sciences and Research. 2011;1(2): 109-116.

[12] Coates AS, Winer EP, Goldhirsch A, Gelber RD, Gnant M, Gebhart MP, Thurlinnman B. Improving The Management of Early Breast Cancer: St. Gallen International Expert Consensus On The Primary Therapy of Early Breast Cancer 2015. European Society For Medical Oncology. Ann Oncol. 2015; 26 (8):33-1546.

[13] Dowsett M, Forbes JF, Bradley J, Ingle A. Aihara T. Aromatase inhibitors versus tamoxifen in early breast cancer: patient-level meta-analysis of the randomised trials. Early Breast Cancer Trialists Collaborative Group (EBCTCG). Lancet Oncology.2015;386(10001):41-1352. 
[14] Untch MC, Thomssen C.Clinical practice decisions in endocrine therapy. Cancer Investigation . 2010; 28(1):4-13.

[15] Rianti E, Tirtawati GA, Novita H. Faktor-faktor yang berhubungan dengan kanker payudara wanita. J.Heal Qual, 2012 ; 3 (1): 10-23.

[16] Rukminingsih F, Murti AT, Fita R, Kartika W. Evaluasi Terapi Adjuvan dan Kejadian Relaps Pada Pasien Premenopousal Early Breast Cancer di RSUP DR. Sardjito Yogyakarta. Jurnal Manajemen dan Pelayanan Farmasi. 2017; 7(1):24-29.

[17] Purwanto H, Handoyo H. Haryono S, Harahap W. PERABOI: Panduan Penatalaksanaan Kanker Payudara 2014.

[18] Dananjaya R. Hubungan golongan obat anti hormonal dengan efek samping pada pasien kanker payudara stadium Dini.[Skripsi].Padang. Fakultas Kedokteran Universitas Andalas; 2017.

[19] Megawati. Gambaran ketahanan hidup lima tahun pasien kanker payudara berdasarkan karakteristik demografi dan faktor klinis di rumah sakit Ciptomangunkusumo tahun 2007-2010 [skripsi]. Jakarta: Universitas Indonesia. 2011:35-39.

[20] Surakasula A, Nagarjunapu GC, Raghavaian KV. A Comparative study of Pre and postmenopousal breast cancer. Risk factors, presentation, Characteristics and Management. J of Research In Pharmacy Practice. 2014;3 (1): 12-18.

[21] Polyak K. Heterogeeity in Breast Cancer. J of Clinical Investigation. 2011; 121(10): 86-3788.

[22] Bedognetti D, Sertoli RM and Pronzato P, Concurrent vs Sequential Adjuvant Chemoterapy and Hormone Therapy in Breast Cancer : A Multicentre Randomized Phase III Trial. JNCI.2011; 103(20): 291539.

[23] Irwan, Azamris, Bachtiar H. Perbandingan Prognosis Subtipe Molekuler Kanker Payudara Antara Pasien Kanker Payudara. Majalah Kedokteran Andalas. 2015;38(3): 208-217.
[24] The Nationale Comprehensive Cancer Network Guideline. 2016. Guideline for Patient Breast Cancer Stage I and II.

[25] Gu R, Jia W, Zeng Y, Rao N, Hu Y, Li S, Wu J, Jin L, Chen L, Long M, Chen K. Comparison of Survival outcomes and Side Effect of TMX Therapy in Premenopousal Estrogen and Progesteron (+) Breast Cancer. BMC Cancer. 2012; 12(161).

[26] Dellapasqu S, Colleoni M, Gelber A and Goldhirsch A. Adjuvant Endocrine Therapy for Premenopausal Women With Early Breast Cancer.American Society of Clinical Oncology. J Clin Oncol. 2005; 23(8):36-1750.

[27] Khambri D. Peran Terapi Hormonal pada kanker Payudara. Majalah Kedokteran Andalas. 2015; 38(1): 64-65.

[28] Gray RG, Rea D, Handley K, Bowden SJ, Perry P, Earl HM, Poole CJ, Bates T. ATTom:Long term effects of continuing adjuvant tamoxifento 10 years versus stopping at 5 years in 6,953 women with early breast cancer. J Clin Oncol 31.2013; 18 (5).

[29] Early Breast Cancer Trialists Collaborative Group. Relevance of breast cancer hormone receptors and other factors to the efficacy ofadjuvant tamoxifen: patient-level meta-analysis of randomised trials. Lancet. 2011; 378(9793) 71-784.

[30] Regan, M.M., P. Neven and A.G. Hurder. 2011. Assessment of letrozole and tamoxifen alone and in sequence for postmenopausal women with steroid hormone receptor-positive breast cancer: the BIG 1-98 randomised clinical trial at 8.1 years median follow-up. Lancet Oncology (12)12:1101-1108

Copyright $\odot 2018$ The author(s). You are free to share (copy and redistribute the material in any medium or format) and adapt (remix, transform, and build upon the material for any purpose, even commercially) under the following terms: Attribution - You must give appropriate credit, provide a link to the license, and indicate if changes were made. You may do so in any reasonable manner, but not in any way that suggests the licensor endorses you or your use; ShareAlike - If you remix,
transform, or build upon the material, you must distribute your contributions under the same license as the original (https://creativecommons.org/licenses/by-sa/4.0/) 